\title{
Penyesuaian Keluarga Warga Kampung Nelayan Desa Tambakbulusan Kabupaten Demak
}

\author{
${ }^{1}$ Titin Suprihatin, ${ }^{2}$ Inhastuti Sugiasih, ${ }^{3}$ Sri Wahyuni \\ ${ }^{1,2}$ Fakultas Psikologi, Universitas Islam Sultan Agung Semarang \\ ${ }^{3}$ Fakultas IImu Keperawatan, Universitas Islam Sultan Agung Semarang \\ Email: titin@unissula.ac.id
}

\begin{abstract}
Abstrak
Penyesuaian dalam keluarga perlu dimiliki oleh orangtua karena dengan adanya penyesuaian dalam keluarga akan memberi dampak positif bagi anak dan orangtua sendiri. Penelitian deskriptif ini bertujuan untuk mengetahui gambaran penyesuaian keluarga pada warga kampung nelayan Desa Tambakbulusan Kabupaten Demak. Fokus penelitian pada orangtua khususnya wanita (ibu) yang telah menikah dan memiliki anak usia kanak-kanak dan remaja. Sebanyak 59 orang dilibatkan sebagai responden dalam penelitian. Alat ukur yang digunakan adalah Parenting and Family Adjustment Scale (PAFAS). Skala pengasuhan terdiri dari 28 aitem dengan reliabilitas Alpha Cronbach 0,627 dan skala penyesuaian dalam keluarga terdiri dari 12 aitem dengan reliabilitas Alpha Cronbach 0,791 . Latar belakang pendidikan orangtua diketahui 15,3\% lulusan perguruan tinggi, 15,3\% lulusan SMA, 33,9\% lulusan SMP, dan $35,6 \%$ lulusan SD. Latar belakang pekerjaan orangtua diketahui $85 \%$ sebagai ibu rumah tangga. Hasil pengukuran diperolah rerata penyesuaian keluarga $(M)=28,7$ dan simpangan baku (SD)=4,5. Berdasarkan hasil kategorisasi diketahui $18,6 \%$ memiliki penyesuaian dalam keluarga yang rendah, $72,9 \%$ memiliki penyesuaian dalam keluarga dalam kategori sedang, dan 8,5\% memiliki penyesuaian dalam keluarga dalam kategori tinggi.
\end{abstract}

Kata Kunci: Penyesuaian Keluarga, Pengasuhan, Orangtua

\section{Pendahuluan}

Masa menjadi orangtua merupakan tahap alamiah yang terjadi dalam kehidupan seseorang. Penyesuaian terhadap masa menjadi orangtua (parenthood) merupakan kriteria terpenting dalam pengalihan dari tanggung jawab individual menjadi tanggungjawab kedewasaan. Masa ini disebut "masa krisis" karena memerlukan banyak perubahan perilaku, nilai dan peran (Hurlock, 2004).

Menikah dan menjadi orangtua berarti membentuk suatu keluarga. Menurut Murdock (Lestari, 2012) keluarga merupakan kelompok sosial yang 
PSISULA: Prosiding Berkala Psikologi

Vol. 1, 2019

E-ISSN: 2715-002X

memiliki karakteristik tinggal bersama, terdapat kerjasama ekonomi, dan terjadi proses reproduksi. Willis (2015) Keluarga adalah sebuah sistem yang didalamnya terjadi komunikasi dua arah (suami-istri) dan komunikasi segala arah bagi semua anggota keluarga. Setiap komponen keluarga berfungsi mengarahkan, membina, dan memberikan perhatian serta kasih sayang kepada semua anggota keluarga (Willis, 2015)

Dalam pengasuhan dan penyesuaian dalam keluarga terdapat 5 domain untuk meneliti hal tersebut; yaitu praktik pengasuhan, kualitas hubungan orangtuaanak, penyesuaian emosional orangtua terhadap pengasuhan, hubungan keluarga yang positif dan kerjasama orangtua (Sanders, Morawska, Haslam, Filus, \& Fletcher, 2014). Kebahagiaan dalam mengasuh sesuatu yang secara umum diharapkan oleh orang tua, dan karenanya banyak membutuhkan usaha dan melibatkan rasa frustrasi (Brooks, 2011). Setiap orang tua akan berbeda dalam pengalaman pengasuhan sehari-hari. Dibutuhkan kemampuan menyesuaikan diri terhadap perubahan dalam keluarga agar tercapai kebahagiaan.

Orangtua yang paling beresiko mengalami kesulitan penyesuaian ialah yang tidak realistis mengenai perubahan, berpandangan negatif terhadap pasangan, merasa pesimis untuk menyelesaikan masalah dan tidak melakukan tindakan apapun untuk mencari solusi yang memuaskan bagi permasalahan yang dihadapi (Brooks, 2011). Beragam dukungan dapat membantu orangtua menyesuaikan diri dengan pengasuhan. Ketika orangtua berhasil memenuhi tuntutan dalam perannya, mereka akan merasa kompeten dan efektif. Perasaan keefektifan diri ini dapat berlanjut, memengaruhi proses pengasuhan. Keluarga dan teman memberikan sumber dukungan formal dan informal yang ikut mempengaruhi proses penyesuaian (Brooks, 2011).

Hurlock (2004) menyatakan penyesuaian perkawinan sebagai proses adaptasi antara suami dan istri dan keduanya dapat mencegah terjadinya konflik dan menyelesaikan konflik dengan baik melalui proses penyesuaian diri. Atwater (Koerner \& Fitzpatrick, 2002) menyebutkan penyesuaian perkawinan sebagai perubahan dan penyesuaian dalam kehidupan perkawinan yang meliputi beberapa 
PSISULA: Prosiding Berkala Psikologi

Vol. 1, 2019

E-ISSN: 2715-002X

aspek dalam kehidupan perkawinan, seperti penyesuaian dalam hidup bersama, penyesuaian peran baru, penyesuaian terhadap komunikasi dan penyelesaian konflik, serta penyesuaian terhadap hubungan seksual dalam perkawinan.

Penelitian longitudinal yang dilakukan oleh Cowan \& Cowan (Brooks, 2011) menghasilkan temuan mengenai dimensi dasar yang melatarbelakangi proses penyesuaian. Penentu utama dalam kemudahan proses penyesuaian adalah kemampuan orang tua dalam menyeimbangkan kebutuhan mereka untuk mandiri dengan kebutuhan untuk merasa dekat dengan orang lain, khususnya dengan pasangan dan anak mereka. Selanjutnya adalah kemampuan berkomunikasi, sikap dalam menghadapi situasi dan orang-orang, kemampuan untuk membagi beban yang sesuai dengan keyakinan/ideologi pasangan, kemampuan untuk mengenali pola perilaku yang dipelajari dari keluarga asal serta kemampuan mengelola konflik dengan efektif.

Perkawinan membutuhkan penyesuaian yang terus menerus. Perkembangan zaman yang semakin pesat, banyaknya perubahan dalam hidup dan banyaknya ketidakpastian, menjadikan kehidupan berkeluarga semakin sulit dan banyak tantangan. Penelitian deskriptif ini bertujuan untuk mengetahui gambaran penyesuaian dalam keluarga pada warga kampung nelayan Desa Tambakbulusan Kabupaten Demak

\section{Metode}

Penelitian ini menggunakan metode kuantitatif. Partisipan dalam penelitian ini berjumlah 59 orangtua (ibu) warna desa Tambakbulusan. Alat ukur yang digunakan adalah Parenting and Family Adjustment Scale (PAFAS). Pengasuhan dan penyesuaian dalam keluarga merupakan sebuah alat ukur yang menilai kemampuan orang tua dalam mengasuh anak, hubungan dalam keluarga baik orang tua dengan anak, dengan pasangannya, dan anggota keluarga yang lain (Sanders, et al., 2014).

Skala pengasuhan terdiri dari 28 aitem dengan reliabilitas Alpha Cronbach 0,627. Skala pengasuhan mencakup aspek-aspek parental consistency, coercive parenting, positive encouragement dan parent-child relationship. Skala penyesuaian 
PSISULA: Prosiding Berkala Psikologi

Vol. 1, 2019

E-ISSN: 2715-002X

dalam keluarga terdiri dari 12 aitem dengan reliabilitas Alpha Cronbach 0,791. Skala ini mencakup aspek parental adjustment, family relationship dan parental teamwork.

Reliabilitas komposit atau composite reliability (CR) pada penelitian yang dilakukan Sanders dkk (2014) untuk parenting scale, yaitu parental consistency $\alpha=0,64$, coercive parenting $\alpha=0,75$, positive encouragement $\alpha=0,70$ dan parent-child relationship $\alpha=0,78$. Sedangkan reliabilitas komposit untuk skala family adjustment diketahui parental adjustment $\alpha=0,85$, family relationship $\alpha=0,76$, dan parental teamwork $\alpha=0,79$. Pada penelitian ini, data yang di analisis hanya skala penyesuaian dalam keluarga. Analisis data menggunakan statistik deskriptif.

\section{Hasil}

Berdasarkan data demografi, menunjukkan bahwa $35,6 \%$ responden memiliki tingkat pendidikan SD, 33,9\% tingkat pendidikan SMP, 15,3\% tingkat pendidikan SMA/SMK, 15,3\% tingkat pendidikan sarjana. Sebagaimana tabel 1 berikut ini:

Tabel 1. Tingkat pendidikan subjek

\begin{tabular}{ccc}
\hline Tingkat Pendidikan & Frekuensi & $\%$ \\
\hline SD & 21 & 35.6 \\
SMP/MTs & 20 & 33.9 \\
SMA/SMK & 9 & 15.3 \\
Sarjana & 9 & 15.3 \\
Total & 59 & 100.0 \\
\hline
\end{tabular}

Berdasarkan skala penyesuaian keluarga (family adjusment) yang diisi subjek, diketahui rerata penyesuaian keluarga 28,71 dengan simpangan baku (SD): 4,47 . 
PSISULA: Prosiding Berkala Psikologi

Vol. 1, 2019

E-ISSN: 2715-002X

Tabel 2. Rata-rata skor penyesuaian keluarga

\begin{tabular}{ccc}
\hline $\mathrm{N}$ & Rerata & Simpangan Baku \\
\hline 59 & 28.71 & 4.472 \\
\hline
\end{tabular}

Berdasarkan data kategori penyesuaian keluarga, 72,9\% subjek penelitian berada dalam kategori sedang, 18,6\% kategori rendah dan 8,5\% kategosi tinggi. Sebagaimana tabel 3.

Tabel 3. Kategori Penyesuaian Keluarga

\begin{tabular}{ccc}
\hline $\begin{array}{c}\text { Kategori } \\
\text { Penyesuaian Keluarga }\end{array}$ & Frekuensi & $\%$ \\
\hline Rendah & 11 & 18.6 \\
Sedang & 43 & 72.9 \\
Tinggi & 5 & 8.5 \\
Total & 59 & 100.0 \\
\hline
\end{tabular}

Grafik perbedaan penyesuaian keluarga dapat dilihat dari gambar 1 berikut:

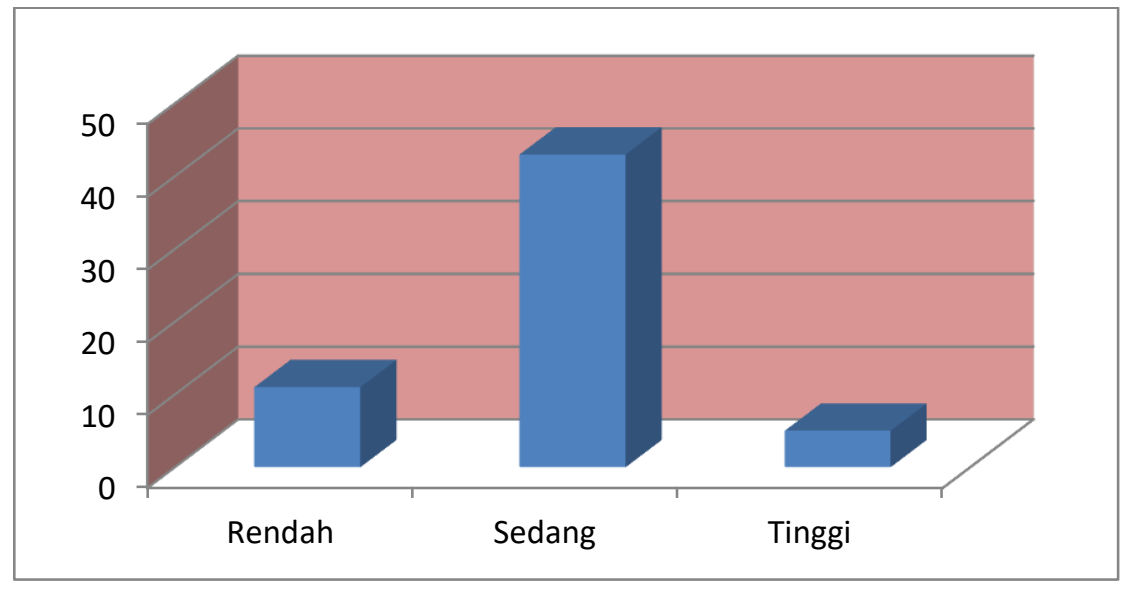

Gambar 1. Grafik Penyesuaian Keluarga

Kategori penyesuaian keluarga berdasarkan tingkat pendidikan, diketahui mayoritas subjek penelitian yang lulusan SD, SMP, SMA dan sarjana berada dalam kategori sedang. Sebagaimana tabel 4. 
PSISULA: Prosiding Berkala Psikologi

Vol. 1, 2019

E-ISSN: 2715-002X

Tabel 4. Tingkat Penyesuaian Keluarga berdasarkan Pendidikan

\begin{tabular}{cccccc}
\hline Tingkat & \multicolumn{4}{c}{ Pendidikan } & Total \\
\cline { 2 - 5 } Penyesuaian Keluarga & SD & SMP & SMA & Sarjana & \\
\hline Tinggi & 6 & 3 & 0 & 2 & 11 \\
Sedang & 12 & 16 & 9 & 6 & 43 \\
Rendah & 3 & 1 & 0 & 1 & 5 \\
Total & 21 & 20 & 9 & 9 & 59 \\
\hline
\end{tabular}

Grafik perbedaan penyesuaian keluarga berdasarkan tingkat pendidikan dapat dilihat dari gambar 2 berikut:

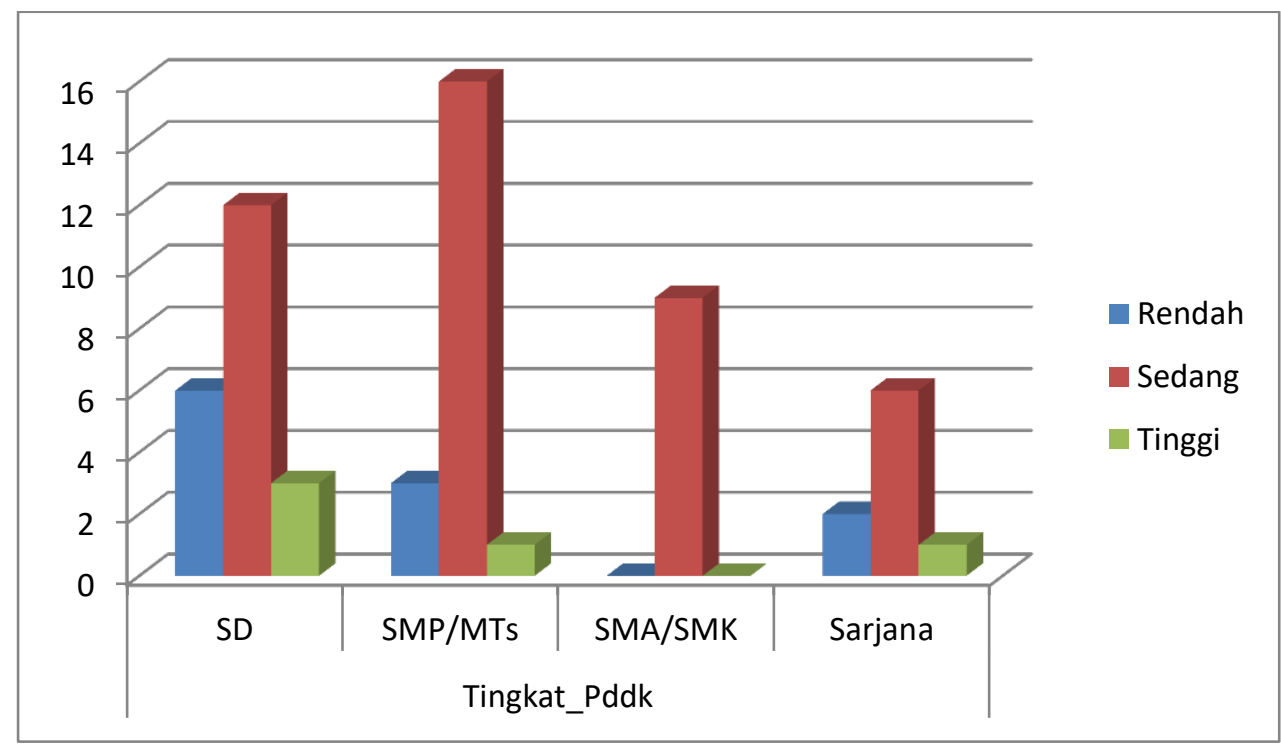

Gambar 2. Grafik Penyesuaian Keluarga Berdasarkan tingkat Pendidikan

\section{Pembahasan}

Hasil penelitian menunjukkan bahwa mayoritas responden (72,9\%) dari 59 orangtua memiliki penyesuaian dalam keluarga (family adjustment) dalam kategori sedang. Hal ini berarti orangtua dapat menyeimbangkan kebutuhan mereka dengan pasangan dan anak; cukup mampu mampu menjalin relasi sosial, cukup mampu berkomunikasi dalam menghadapi situasi dan orang-orang, mampu untuk membagi beban dengan pasangan, serta cukup mampu mengelola konflik dengan efektif.

Penyesuaian diri yang positif ditandai oleh adanya kemampuan beradaptasi dengan perubahan yang terjadi pada diri sendiri, pada pasangan atau pada 
PSISULA: Prosiding Berkala Psikologi

Vol. 1, 2019

E-ISSN: 2715-002X

lingkungan perkawinan (Driver \& Gottman 2004; Pradipta \& Prihanto 2011). Adanya penyesuaian dalam keluarga memberi dampak positif bagi anak dan orangtua sendiri. Sebagaimana penelitian Robinson \& Anderson terhadap 69 pasangan menikah menunjukkan bahwa semakin positif penyesuaian perkawinan, semakin sedikit jumlah perilaku masalah anak. Adanya kehangatan, berkorelasi negatif dengan masalah perilaku anak di rumah (Robinson, 1983). Ratnasari \& Kuntoro (2017) juga membuktikan bahwa parenting stress, pengasuhan dan penyesuaian dalam keluarga memiliki hubungan perilaku kekerasan anak dalam rumah tangga. Semakin baik pengasuhan dan penyesuaian dalam keluarga, akan meminimalisir perilaku kekerasan anak.

Adapun kriteria keberhasilan dalam penyesuaian terhadap perkawinan adalah: adanya kebahagiaan suami-istri, hubungan yang baik dengan anak dan orangtua, penyesuaian yang baik dari anak-anak, kemampuan untuk memperoleh kepuasan dari perbedaan pendapat, adanya kebersamaan, adanya penyesuaian yang baik dalam masalah keuangan dan adanya penyesuaian yang baik dari pihak keluarga pasangan (Hurlock, 2004).

Hasil penelitian juga menunjukkan bahwa penyesuaian keluarga untuk semua level/tingkat pendidikan mayoritas responden berada dalam kategori sedang. Hal ini mengindikasikan bahwa penyesuaian dalam keluarga tidak dipengaruhi oleh tingkat pendidikan. Semua orang tua dengan berbagai latar belakang pendidikan menyadari pentingnya pengasuhan dan penyesuaian dalam keluarga.

\section{Kesimpulan}

Penyesuaian dalam keluarga (family adjustment) pada warga desa Tambakbulusan termasuk dalam kategori sedang. Hal ini berarti orangtua cukup mampu menyeimbangkan kebutuhan mereka dengan pasangan dan anak; cukup mampu mampu menjalin relasi sosial, cukup mampu berkomunikasi dalam menghadapi situasi dan orang-orang, mampu untuk membagi beban dengan pasangan, serta cukup mampu mengelola konflik dengan efektif. 
PSISULA: Prosiding Berkala Psikologi

Vol. 1, 2019

E-ISSN: 2715-002X

\section{Daftar Pustaka}

Brooks, J. (2011). The process of parenting. (R. Fajar, Trans.) Yogyakarta: Pustaka Pelajar.

Driver, J.L \& Gottman, J.M. (2004). Daily marital interaction and positive affect during marital conflict among newlywed couples. Family Process Journal, 43, 3, 301-314

Hossain, S. M., Huq, S., Adhikari, B., Zai, S. Z., \& Haque, S. M. (2015). Parenting skills and child behavior: A cross-sectional study in some selected areas of Nepal. South East Asia Journal of Public Health, 5(1), 44-56.

Hurlock, E. B. (2004). Psikologi perkembangan: Suatu pendekatan sepanjang rentang kehidupan. (S. Istiwidayanti, Trans.) Jakarta: Erlangga.

Lestari, S. (2012). Psikologi keluarga: Penanaman nilai dan penanganan konflik dalam keluarga . Jakarta: Kencana.

Koerner, A.F., \& Fitzpatrick, M.A. (2002). Non verbal communication and marital adjustment and satisfaction: The role of decoding relationship relevan and relationship irrelevan affect. Communication Monographs Journal, 69,1, 3351

Pradipta, M. \& Prihanto, S. (2011). Newlywed couples' Marital Adjustment. Anima, $26,3,214-219$

Ratnasari, K.A., \& Kuntoro. (2017). Hubungan parenting stress, pengasuhan dan penyesuaian dalam keluarga terhadap perilaku kekerasan anak dalam rumah tangga. Jurnal Manajemen Kesehatan, 3, 1, 86-98

Robinson, E. \& Anderson. (1983). Family adjustment, parental attitudes, and social desirability. Journal Abnorm Child Psychology, 11(2), 247-256. Retrieved from https://doi.org/10.1007/BF00912089

Sanders, M. R., Morawska, A., Haslam, D. M., Filus, A., \& Fletcher, R. (2014). Parenting and Family Adjustment Scales (PAFAS): Validation of brief parentreport measure for use in assessment of parenting skill and family relationship. Child Psychiatry and Human Development, 45(3), 255-272. doi:10.1007/s10578-013-0397-3

Willis, S. S. (2015). Konseling keluarga. Bandung: Alfabeta. 